\title{
Application of crushed shells Cristaria plicata to separation cadmium and chromium from polluted water by static sorption
}

\author{
( 2020 Tran Hai Dang ${ }^{1}$, Rudakov O.B. ${ }^{2}$, Khorokhordina E.A. ${ }^{2}$, \\ Tran Thi Pha ${ }^{1}$, Ban Thi My \\ ${ }^{1}$ Thai Nguyen University of Agriculture and Forestry, Vietnam \\ ${ }^{2}$ Voronezh State Technical University, Voronezh, Russian Federation
}

Received 2.08.2020

DOI: $10.17308 /$ sorpchrom.2020.20/3047

Cristaria plicata is a species of freshwater mollusk in the genus Cristaria of the family Unionidae. Cristaria plicata shells are available natural raw materials in Vietnam for the production of sorbents that can absorb many pollutants from wastewater. The most important pollutants are heavy metals. The aim of the study was to study the possibility of using powders from Cristaria plicata shells to purify contaminated water from heavy metals such as $\mathrm{Cd}$ and $\mathrm{Cr}$ by sorption method. A technology for obtaining a sorbent has been developed. After collection, the shells were washed, dried and ground to a size of no more than $0.5 \mathrm{~mm}$, then the powder was soaked in distilled water for 10 hours, dried to a constant weight and sieved through sieves, collecting a fraction with a particle size of about $0.5 \mathrm{~mm}$. Microscopic studies showed that the sorbent particles from the shells of Cristaria plicata contained pores with a diameter of 4.5 to 8.2 microns and a length of 15.9 to 27.6 microns. The static sorption method was used. The $\mathrm{Cd}$ and $\mathrm{Cr}$ content in water samples before and after sorption was performed by atomic absorption spectrophotometry. It is shown that the sorbent from the shell material of Cristaria plicata can be used quite effectively for wastewater treatment from $\mathrm{Cd}$ and $\mathrm{Cr}$. It was found that with an increase in the mass fraction of the powder in the treated water, the concentration of $\mathrm{Cr}$ and $\mathrm{Cd}$ in this water noticeably decreases. The $\mathrm{Cr}$ content drops by $29.5-45.5 \%$ after shaking for 60 minutes, while the $\mathrm{Cd}$ content drops by $91.6-96.9 \%$. The absorption capacity of the sorbent from the shells of Cristaria plicata depends on the initial concentrations of $\mathrm{Cr}$ and $\mathrm{Cd}$, the higher the initial concentration, the more pollutants are absorbed by the sorbent. The best effect of sorption purification is observed at the initial concentrations of $\mathrm{Cd} 1 \mathrm{mg} / \mathrm{l}$ and $\mathrm{Cr} 20 \mathrm{mg} / \mathrm{l}$. For maximum Cd allocation, the recommended processing time is $40 \div 60$ minutes, and for $\mathrm{Cr}-80 \div 100$ minutes.

Keywords: polluted water, freshwater shellfish, heavy metals, static sorption, cadmium, chromium

\section{Introduction}

Heavy metals contamination, radionuclides and other inorganic chemicals are problems in many countries, including Vietnam. The cause may come from nature, however, most of it come from the product created by human activities. Remarkable activities are mining, waste from heavy industry, petroleum production, fertilizer, etc... Most of that waste is discharged directly into the environment without treatment. Therefore, it creates enormous pressure on the ecosystem and environmental protection activities. In addition, heavy metal pollution in soil, water and air is causing many harm to people's health [1-5].

Cristaria plicata is a freshwater mollusk species in the genus Cristaria of the Unionidae family. In Vietnam, Cristaria plicata shells are an affordable natural raw material for the manufacture of sorbents that are capable of absorbing many pollutants from wastewater. Pearl's shell consists of 3 layers: the horny layer, the limestone layer, the na- 
cre layer. The limestone layer, which has a lot of internal pores as it characteristics, is capable of retaining some surface matter, so this could be a good adsorbent material. Pearl's shell is a natural material capable of absorbing many substances in wastewater, especially heavy metals and a common material easily found in nature. Inhabits river and lake water bodies, prefers silty-sandy soils.

\section{Methods}

Research subjects. The subjects of this study is self-made solutions containing Cadmium, Chromium in the laboratory and the pearl's shells are grinded to sizes below $0.2 \mathrm{~mm}$. Experiments conducted in the laboratory.

Research content. Study on characteristics of Cristaria plicata sheel. Assess the effects of $\mathrm{Cr}, \mathrm{Cd}$ concentration inputs to the adsorption capability of Cristaria plicata sheel. Assess the effects of the shell content on the ability to remove $\mathrm{Cr}, \mathrm{Cd}$ in polluted wastewater. Assess the effect of mixing time on the efficiency of $\mathrm{Cr}$ and $\mathrm{Cd}$ treatment in polluted wastewater of Cristaria plicata sheel.

Methods of collecting secondary data. Gather the necessary documents, data and information for the purpose of the study of the thin-shelled clam shell, information on chromium including the amount of chromium in the environment and the impact of chromium on the organism.

Experimental design. Experiments were conducted by static adsorption method with triangle flasks containing $50 \mathrm{ml} \mathrm{Cr^{6+ }}$ or $\mathrm{Cd}^{2+}$ solution. Adding shell contents into the flasks containing the solution and mixing on the shaker at $60 \mathrm{rpm}$ at room temperature and for the specified time for adsorption to occur. Then filter paper was used to separate the material from the mixed solution and take $\mathrm{Cd}^{2+}$ and $\mathrm{Cr}$ solution samples to analyze by applying AAS spectrophotometer.

The experiment assesses the effects of mixing time factors, $\mathrm{Cr}^{6+}, \mathrm{Cd}^{2+}$ concentration inputs and absorbed shell contents on treatment efficiency. Each experimental formula did 3 replicates.

Experiment 1. Effect of the concentration of $\mathrm{Cr}, \mathrm{Cd}$ on the absorption capacity of Cristaria plicata shells. Effect of $\mathrm{Cr}$ concentration: (5 formulas) Adding $500 \mathrm{mg}$ of shell contents into $50 \mathrm{ml}$ of $\mathrm{Cr}^{6+}$ solution with the different concentrations: 5, 10, 15, 20, $25 \mathrm{mg} / 1$ and mixing on a shaker for 60 minutes. Effect of Cd concentration: ( 5 formulas) Adding $500 \mathrm{mg}$ of shell contents into $50 \mathrm{ml}$ of $\mathrm{Cd}^{2+}$ solution with the different concentrations: 0.5 , $1.0,2,5,10 \mathrm{mg} / 1$ and mixing on a shaker for 60 minutes.

Experiment 2. Influence of pearl shell content on the ability to remove $\mathrm{Cr}$ and $\mathrm{Cd}$. Effect of pearl shell content on Cr removal: ( 5 formulas) Adding the amount of shell contents $100,200,300,400,500 \mathrm{mg}$ to $50 \mathrm{ml} \mathrm{Cr}^{6+}$ solution $20 \mathrm{mg} / 1$ and mixing on the machine for 60 minutes. Effect of pearl shell content on Cd removal: (5 formulas) Adding the amount of shell contents $250,500,750,1000,2000 \mathrm{mg}$ into $50 \mathrm{ml} \mathrm{Cd}^{2+}$ solution $20 \mathrm{mg} / 1$ and mixing on the machine for 60 minutes.

Experiment 3. Effect of mixing time on $\mathrm{Cr}$ and $\mathrm{Cd}$ removal performance by Cristaria plicata shells. The effect of mixing time on the performance of $\mathrm{Cr}$ removal: ( 5 formulas) Adding $400 \mathrm{mg}$ of shell contents into $50 \mathrm{ml}$ of $\mathrm{Cr}^{6+}$ solution $20 \mathrm{mg} / \mathrm{l}$, mixing with the time of 20,40, 60, 80 and 100 minutes, respectively. The effect of mixing time on the performance of $\mathrm{Cd}$ treatment: (5 formulas) Adding $500 \mathrm{mg}$ of shell contents into $50 \mathrm{ml}$ of $\mathrm{Cd}^{2+}$ solution $1 \mathrm{mg} / \mathrm{l}$, mixing with the time of 20, 40, 60, 80 and 100 minutes.

Laboratory analysis methods. $\mathrm{Cd}$ and $\mathrm{Cr}$ mobilize were analyzed by AAS spectrophotometer.

Tran Hai Dang et al. / Сорбционные и хроматографические процессы. 2020. Т. 20. № 5. С. 556-564 
Synthesis and analysis data and documents. The statistics were processed by SAS software and Microsoft Excel.

Conduct experiments. Fabrication of adsorbent material from pearl shell. The process of shell treatment is described in the following fig. 1 .

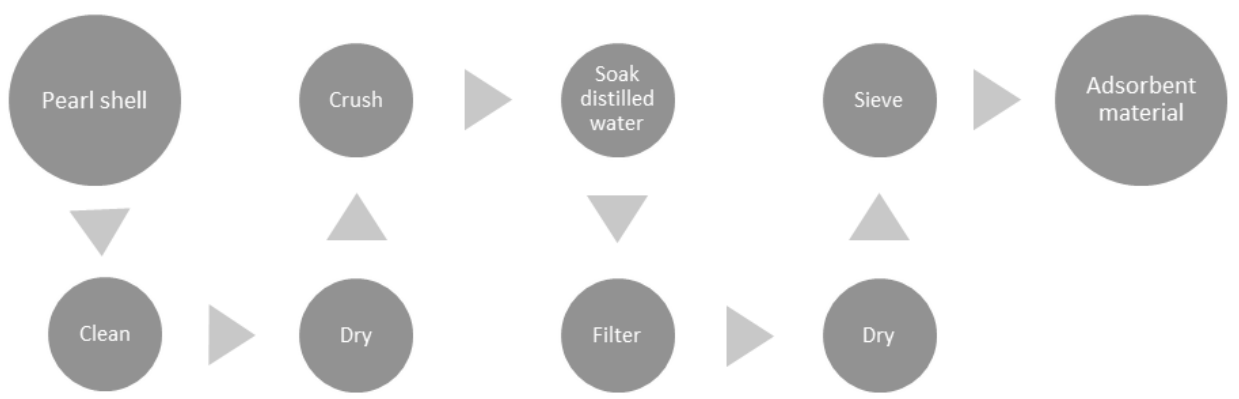

Fig. 1. The process of handling the shell into adsorption material

Shells after being collected are washed then dry and grind to size below $0.5 \mathrm{~mm}$. Next, it is soaked in distilled water for 10 hours, then filtered, dried for a second time to a constant weight and brought to light, sieved to remove materials larger than $0.5 \mathrm{~mm}$ (fig. 2 ).

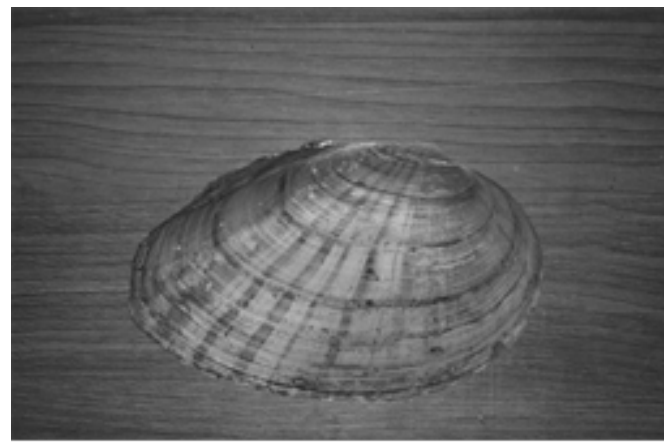

Pearl's shell

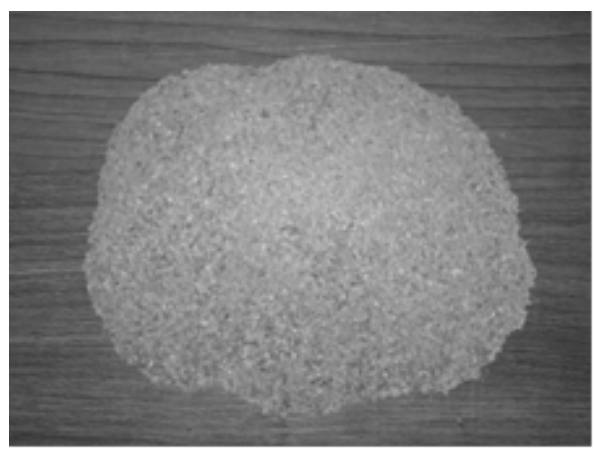

Pearl's shell powder

Fig. 2. Pearl's shell before and after grinding

\section{Results and discussion}

Pearl's shell adsorption characteristics. To observe the characteristics of pearl's shell adsorption, it is needed to enlarge $\mathrm{x} 100$ and high oil soaked to visualize, count and measure bacteria. The results showed that there were many cracks on the shell perpendicular to the shell (fig. 3-4). The mature subshell consists of thin matrix layers interspersed with $\sim 500 \mathrm{~nm}$ thick layers of calcium carbonate minerals parallel to the inner shell surface as well as the cell's shells in the coating. The matrix layers are so thin that they cannot be detected by the naked eye (arrows indicate the position of the matrix). The significant difference between the superstructure formed by the different mollusk layers is the persistence of the orientation of the crystals in the direction perpendicular to the surface of the shell: the two edges of the two aragonite crystals of the Layers close to each other never exist, while in Cephalopods [1] form a stack of $\sim 50$ vertical flat bricks in the vertical direction.

Single Aragonite pellets are nucleated on the matrix ground and grow rapidly in a direction perpendicular to the surface of the shell (crystal-shaped axis c). Parallel growth with the thin layer after the Aragonite layer reaches its maximum thickness. The growing crystal is hexagonal. They are just like the irregular polygons when they grow and merge 
together in a continuous layer. The image shows three characteristic, well-defined hierarchies of overlapping development layers. The arrow indicates the direction of growth. The coating cells are placed next to the steps in living organisms.

The shell of the mussel is characterized by a break as shown in Figure 3.c. In Figure 3 (A) the breaking position is shown by an arrow. It is illustrated as the red bars in the picture. (B) illustrates the part of the shell where the «after crack» measurements are made.

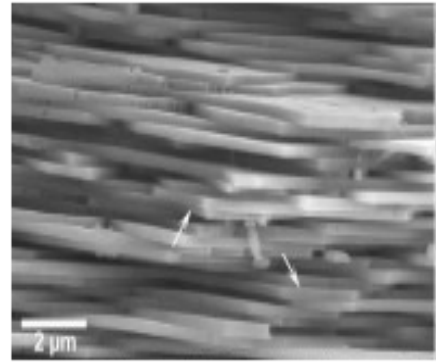

3.a. Cracks on the shell

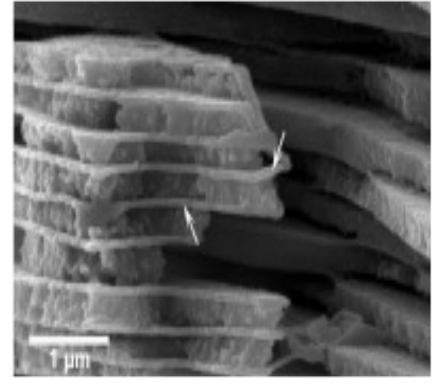

3.b. Layers of $60-70 \mathrm{~nm}$

Fig 3. Shell structure

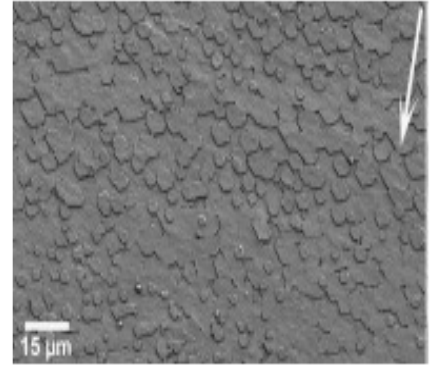

3.c. Front side of the nacre layer on the inner surface
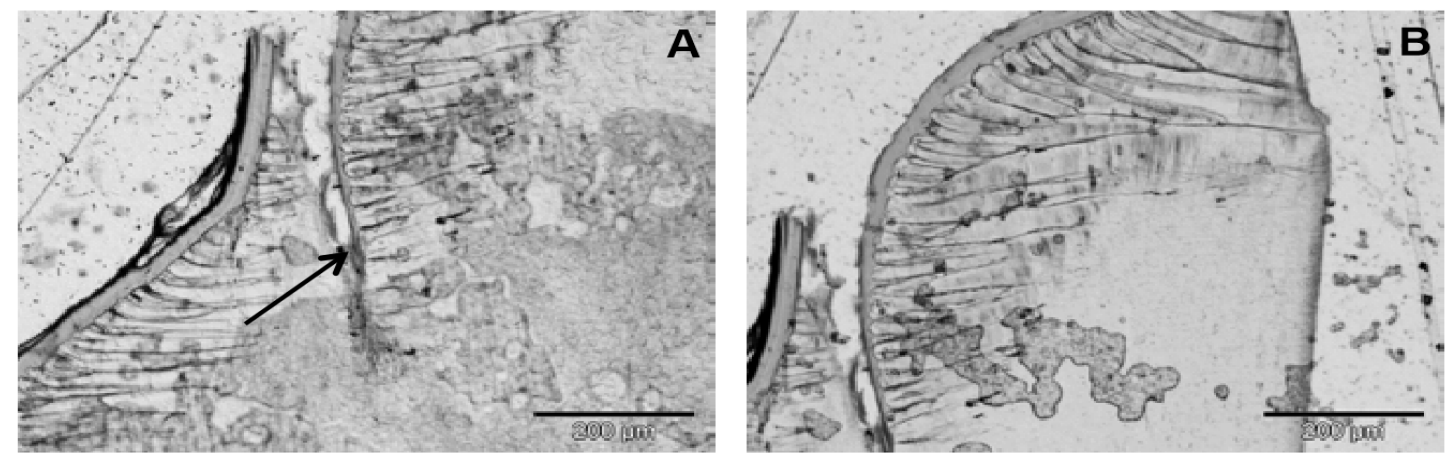

Fig. 4. Characteristics of shell's breakdown

Explaining this characteristic, in the SEM image, it shows that in the shell of the pearl, there are always exist of bacterias which are arranged in a contiguous order, distributed from the outer layer to the inside. Cracking in the shell is due to a change in the size of the bacteria, including the width and length during which bacteria live on the shell. The smallest width measured is $4.50 \mu \mathrm{m}$ and the maximum width is $15.94 \mu \mathrm{m}$, the minimum value measured by covers taken from other areas is: $8.17 \mu \mathrm{m}$ and the maximum value is $27.56 \mu \mathrm{m}$ (Fig. 4) shows that this difference depends on the growth of microorganisms and may be due to both mussel habitat but no conclusions about environment and locality can be made due to lack of information and the fact that it is impossible to measure a year in a row and there is no information about the lifetime.

There is also a big difference in quality between the layers of shell, although they all have the same arrangement and structure. In every thin piece removed from the original shell it is evident that the degree of cracking is different for this, as a result of the difference that exists singly and population or compete in the community, among organisms in a population.

Thus, the structure of the shell always exists with small holes having a width of from 4.50 to $8.17 \mu \mathrm{m}$ and a length of $15.94 \mu \mathrm{m}$ to $27.56 \mu \mathrm{m}$ and gradually decreasing from the outer surface of the shell. For this reason, pearl shell has the ability to adsorb many 
substances in the water and has the potential to be used in handling heavy metal adsorption in general as well as Cadmium itself, while it like other adsorbent materials in desorption capacity and enrich the metal.

Assess the effect of input $\mathrm{Cr}, \mathrm{Cd}$ concentration on the shell adsorption capacity. The results of the effects of $\mathrm{Cr}$ and $\mathrm{Cd}$ concentrations are shown in Table 1, fig. 5.

Table 1 . The effect of $\mathrm{Cr}, \mathrm{Cd}$ concentration on the shell adsorption capacity

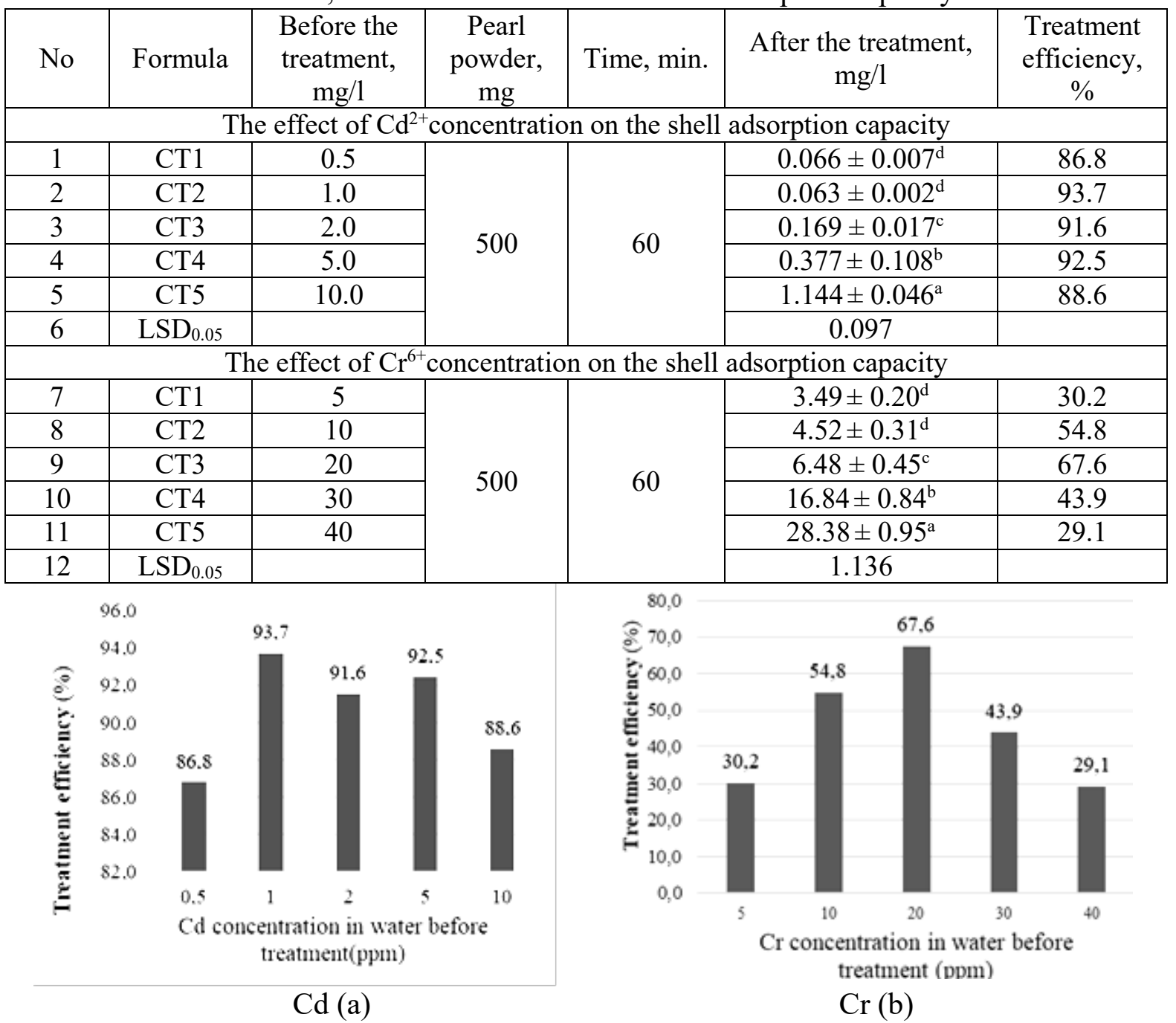

Fig 5. Cd and $\mathrm{Cr}$ treatment efficiency in water has different concentrations

With a shell content of $500 \mathrm{mg}$ and shaking time of $60 \mathrm{~min}$ with different concentrations of input in the ascending direction, the treatment efficiency decreases from 7 to 15 times corresponding to the processing efficiency of 86.8-93.7\%. The results also show that the greater the concentration of $\mathrm{Cd}^{2+}$ will give the higher concentration of $\mathrm{Cd}^{2+}$ after processing, the ability to treat $\mathrm{Cd}^{2+}$ with mussel powder by shaking method for the highest treatment results when applied in according to the formula $2: \mathrm{C} 2=1.0 \mathrm{mg} / 1$.

With shell content of $400 \mathrm{mg}$ and shaking time of 80 minutes with different concentrations of input in the ascending direction, the treatment efficiency decreased by $30 \div 67.6 \%$ compared to the initial concentration. The results also show that the higher the concentration of input $\mathrm{Cr}$, the higher the concentration of $\mathrm{Cr}$ after treatment, the ability to remove $\mathrm{Cr}$ with mussel powder by mixing method for the highest treatment result when applied according to the formula 3: $\mathrm{C} 3=20 \mathrm{mg} / \mathrm{l}$, treatment efficiency decreased $67.6 \%$. 
Effect of shell content on the ability to remove $\mathrm{Cd}^{2+}$ and $\mathrm{Cr}^{6+}$ (tab.2, fig.6). With the input concentration of $1.0 \mathrm{mg} / \mathrm{l}$ with the content of shell powder according to different formulas after shaking for 60 minutes, the processing efficiency varies from 91.6 to $96.9 \%$. Comparing the initial pollutant concentration after the experiment with the ratio of mussel shell powder ratio according to the formulas showed that: The higher the adsorption efficiency of the thin-shelled shellfish powder for $\mathrm{Cd}^{2+}$, the higher the fixed ability of the bigger it. The trend of reducing this concentration decreased with the increase rate of Cristaria plicata sheel powder but the decrease was not significantly different.

Table 2. Effect of shell content on the ability to remove $\mathrm{Cd}^{2+}$ and $\mathrm{Cr}^{6+}$

\begin{tabular}{|c|c|c|c|c|c|c|}
\hline No & Formula & $\begin{array}{c}\text { Before the } \\
\text { treatment, } \\
\mathrm{mg} / \mathrm{c}\end{array}$ & $\begin{array}{c}\text { Pearl } \\
\text { powder, } \\
\mathrm{mg}\end{array}$ & \multirow{2}{*}{$\begin{array}{c}\text { Time, } \\
\text { minutes }\end{array}$} & $\begin{array}{c}\text { After the treat- } \\
\text { ment, mg/l }\end{array}$ & $\begin{array}{c}\text { Treatment } \\
\text { efficiency, } \\
\%\end{array}$ \\
\hline \multicolumn{7}{|c|}{} \\
\end{tabular}

With the input concentration of $20 \mathrm{mg} / 1$ with the content of shell powder in different formulas after shaking for $60 \mathrm{~min}$, the processing efficiency decreased by 29.5 $45.5 \%$. Comparing the initial pollutant concentration after the experiment with the ratio of shell powder ratio according to the formulas showed that: the higher the adsorption efficiency of the Cristaria plicata sheel for $\mathrm{Cr}$, the more fixed the the bigger it. The ability to remove $\mathrm{Cr}$ with pearl shell powder by shaking method gives the highest treatment results when applying the formula 3 : $\mathrm{CT}=400 \mathrm{mg}$ of pearl shell powder. The trend of reducing this concentration decreased with the increase rate of Cristaria plicata sheel powder but the decrease was not significantly different.

The influence of mixing time on $\mathrm{Cd}^{2+}$ treatment efficiency of Cristaria plicata sheels (tab. 3, fig. 7). With the input concentration of $\mathrm{C}=1.0 \mathrm{mg} / \mathrm{L}$, the content of shell powder $500 \mathrm{mg}$ is added to the shaker at different time intervals in the direction of increase, resulting in the concentration of $\mathrm{Cd}^{2+}$ with reduced treatment efficiency compared to the original. from 6 to 20 times, respectively $84-95.1 \%$.

The results showed that in formula 1 with shaking time of 20 minutes, the value of the highest concentration of $\mathrm{Cd}^{2+}$ or the lowest adsorption capacity of $\mathrm{Cd}^{2+}$. in CT2 with a shaking time of 40 minutes, the adsorption efficiency was more effective than the remaining formulas.

With the input concentration of $C=20 \mathrm{mg} / 1$, the content of shell powder $400 \mathrm{mg}$ put into the shaker at different time intervals in the direction of increasing the $\mathrm{Cr}$ concentration results with a reduction of treatment efficiency compared to the original $18.8-41.7 \%$. The results showed that in formula 4 with the shaking time of 80 minutes, the value of the $\mathrm{Cr}$ concentration was treated with the highest efficiency of $41.7 \%$. 


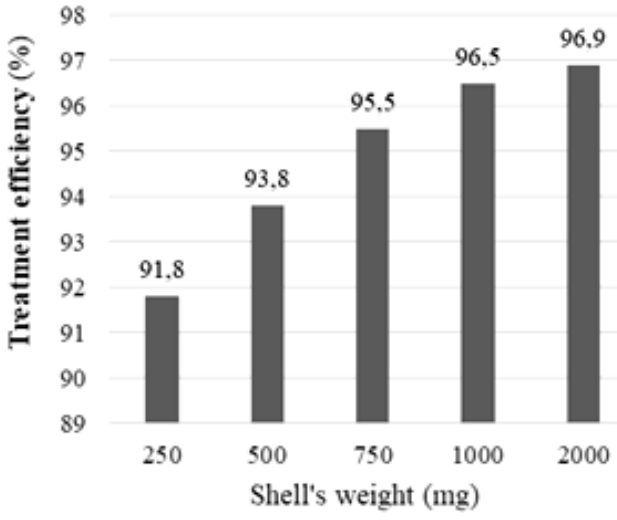

$\mathrm{Cd}(\mathrm{a})$

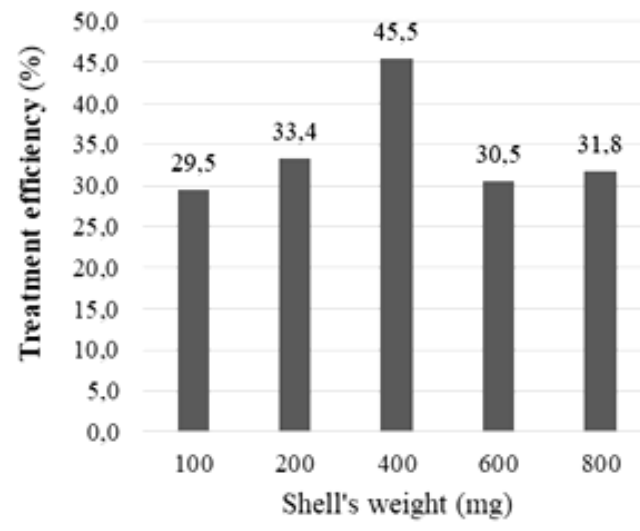

$\mathrm{Cr}(\mathrm{b})$

Fig 6. $\mathrm{Cd}$ and $\mathrm{Cr}$ treatment efficiency in water has different amounts of shell

Table 3. Effect of mixing time on $\mathrm{Cd}^{2+}$ and $\mathrm{Cr}^{6+}$ treatment capacity of pearl sheels

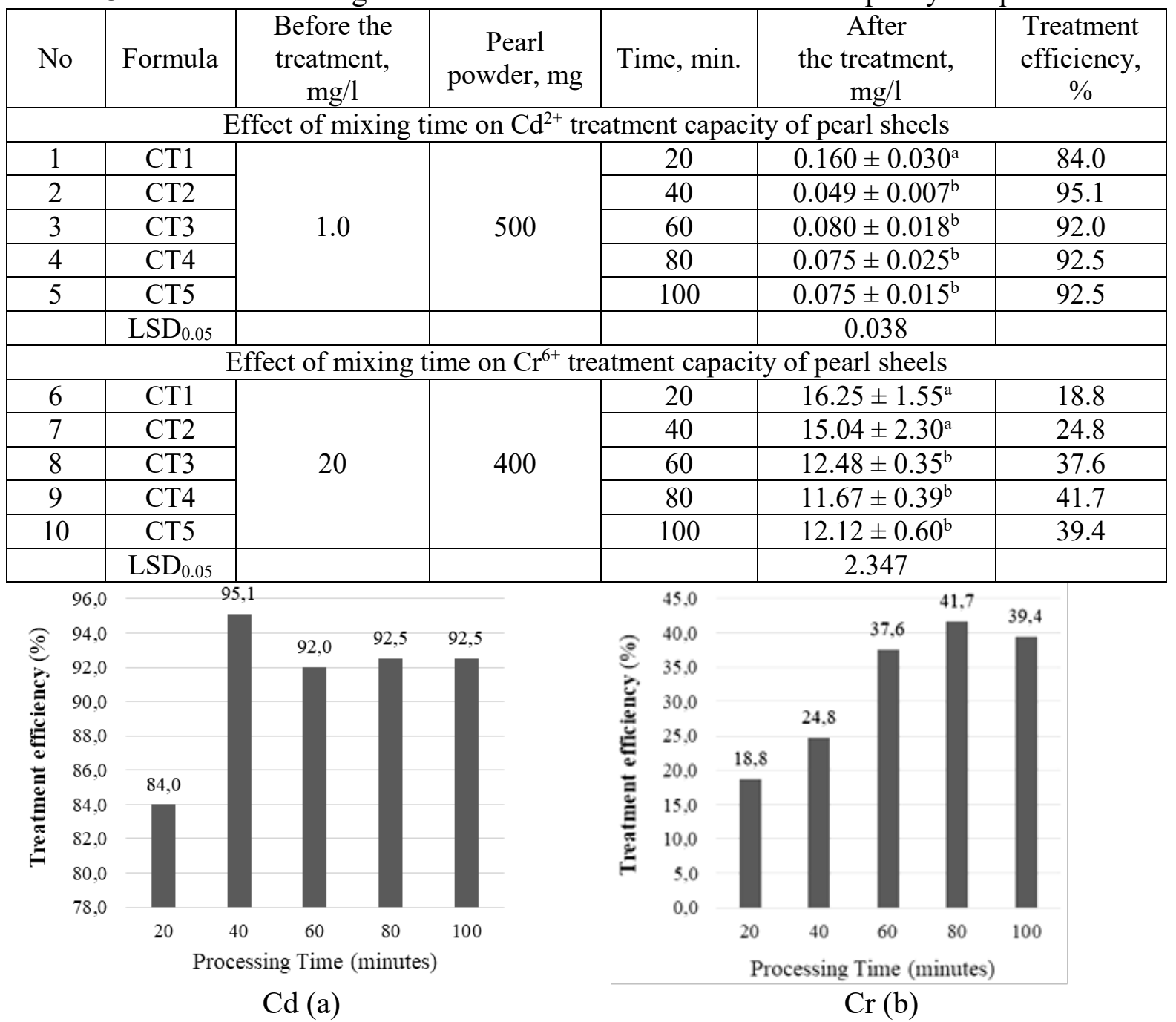

Fig 7. Cd, Cr treatment efficiency with different mixing times

\section{Conclusion}

The pearl shell is made up of small holes always having a width from 4.50 to 8.17 $\mu \mathrm{m}$ and a length of 15.94 to $27.56 \mu \mathrm{m}$ and gradually decreasing from the outer surface of 
the shell. Therefore, mussels have the ability to adsorb many substances in the water. The Cristaria plicata sheel powder has the potential to be used to remove heavy metals in water. According to the research results, the higher the ratio of pearl shell powder, the lower the proportion of $\mathrm{Cr}, \mathrm{Cd}$ concentration in water. The change of the content of pearl shell powder increased with a defined $\mathrm{Cr}$ concentration after shaking for 60 minutes, the treatment efficiency reached $29.5-45.5 \%$ and $\mathrm{Cd}$ achieved the higher efficiency of 91.6$96.9 \%$. However, the results showed no significant difference. The change of shaking time affects the concentration of $\mathrm{Cr}, \mathrm{Cd}$ output after the experiment, the treatment efficiency reaches $29.5-45.5 \%$ for $\mathrm{Cr}$ and and $91.6-96.9 \%$ for $\mathrm{Cd}$. The absorption capacity of Cristaria plicata sheel powder is affected by the input concentrations of $\mathrm{Cr}$ and $\mathrm{Cd}, \mathrm{Cd}$ and $\mathrm{Cr}$ treatment efficiency respectively changes are $86.8-93.7 \%$ and $30-67.6 \%$. It was found that the higher the input concentration will give the greater concentration after treatment, but the results show that the input concentration effect will give the highest adsorption results when applied according by $\mathrm{C}=20 \mathrm{mg} / 1$ for $\mathrm{Cr}$ and $\mathrm{C}=1 \mathrm{mg} / 1$ for $\mathrm{Cd}$.

\title{
References
}

1. Shinkai Y, Duong V.T., Sumi D., Doan C, Kumagai Y., Journal of Health Science, 2007, Vol. 53, No 3, pp. 344-346. doi:10.1248/jhs.53.344c

2. Chu N.K., Nguyen V.N., Le T.S., Ha M.N. et al., Soil Science \& Plant Nutrition, 2010, Vol. 56, No 2, pp. 344-356. doi: 10.1111/j.1747-0765.2010.00451.x

3. Ho H.H., Swennen R., Van Damme A.V, Geologica Belgica, 2010, Vol. 13, No 2, pp. 3747.
4. Nguyen T.L.H., Ohtsubo M., Li L., Higashi T., Kanayama M., Communications in Soil Science and Plant Analysis, 2010, Vol. 41, No 4, pp. 390-407. doi: 10.1080/00103620903494350

5. Nguyen V.A., Bang S.B., Pham H.V., Kim K.W., Environment International, 2009, Vol. 35, No 3, pp. 466-472. doi: 10.1016/j.envint.2008.07.014

\section{Применение измельченных раковин Cristaria plicata для извлечения кадмия и хрома из загрязненной воды методом статической сорбции}

\author{
(C) 2020 Чан Хай Данг ${ }^{1}$, Рудаков О.Б. ${ }^{2}$, Хорохордина Е.А. ${ }^{2}$, \\ Чан Тхи Фа' ${ }^{1}$ Бан Тхи Ми \\ ${ }^{1}$ Тхайнгуенский университет сельского и лесного хозяйства, Вьетнам \\ ${ }^{2}$ Воронежский государственный технический университет, Воронеж, Россия
}

\begin{abstract}
Cristaria plicata - вид пресноводных моллюсков в составе рода Cristaria семейства Unionidae. Раковины Cristaria plicata являются во Вьетнаме доступным натуральным сырьем для изготовления сорбентов, которые способны поглощать многие загрязняющие вещества из сточных вод. К наиболее важным загрязнителям относятся тяжелые металлы. Целью исследования было изучение возможности применения порошков из раковин Cristaria plicata для очистки загрязненной воды от таких тяжелых металлов как $\mathrm{Cd}$ и $\mathrm{Cr}$ сорбционным методом. Разработана технология получения сорбента. После сбора раковины промывали, сушили и измельчали до размера не более 0.5 мм, затем порошок вымачивали в дистиллированной воде в течение 10 часов, сушили до постоянного веса и просеивали через сита, собирая фракцию с размером частиц около 0.5 мм. Микроскопические исследования показали, что частицы сорбента из раковин Cristaria plicata, содержали поры, имеющие диаметр от 4.5 до 8.2 мкм и длину от 15.9 до 27.6 мкм. Был использован метод статической сорбции. Содержание Сd и $\mathrm{Cr}$ в пробах воды до и после сорбции выполняли методом атомно-абсорбционной спектрофотометрии. Показано, что сорбент из материала раковин Cristaria plicata может достаточно эффективно применяться для очистки сточных вод от $\mathrm{Cd}$ и $\mathrm{Cr}$. Найдено, что при увеличении массовой доли по-
\end{abstract}


рошка в очищаемой воде, концентрация $\mathrm{Cr}$ и $\mathrm{Cd}$ в этой воде заметно падает. Содержание $\mathrm{Cr}$ после встряхивания в течение 60 минут падает на 29.5-45.5\%, а Cd - на 91.6-96.9\%. Поглощающая способность сорбента из раковин Cristaria plicata зависит от исходных концентраций $\mathrm{Cr}$ и $\mathrm{Cd}$, чем выше исходная концентрация, тем большее количество загрязнителей поглощается сорбентом. Наилучший эффект сорбционной очистки наблюдается при исходных концентрациях $\mathrm{Cd} 1 \mathrm{мг} / \mathrm{gm}^{3}$ и $\mathrm{Cr} 20$ мг/дм³. Для максимального выделения Сd рекомендуемое время обработки 40-60 мин, а для $\mathrm{Cr}-80-100$ мин.

Ключевые слова: загрязненная вода, пресноводные моллюски, тяжелые металлы, статическая сорбция, кадмий, хром

Чан Хай Данг - к.Х.н., заместитель заведующего кафедрой экологических технологий факультета окружающей среды Тайнгуенского университета сельского и лесного хозяйства, Вьетнам

Тран Тхи Пха -- заведующий кафедрой экологических наук и менеджмента факультета окружающей среды Тайнгуенского университета сельского и лесного хозяйства, Вьетнам

Бан Тхи Ми - лаборант кафедры экологических наук и менеджмента факультета окружающей среды Тайнгуенского университета сельского и лесного хозяйства, Вьетнам

Рудаков Олег Борисович - д.Х.н., професcop, заведующий кафедрой химии и химической технологии материалов, Воронежский государственный технический университет, Воронеж, Россия

Хорохордина Елена Александровна - доцент кафедры химии и химической технологии материалов, Воронежский государственный технический университет, Воронеж, Россия
Tran Hai Dang - Vice Head of Department Environmental Technology, Faculty of Environment, Thai Nguyen University of Agriculture and Forestry, Vietnam, Email: tranhaidang@tuaf.edu.vn

Tran Thi Pha - Head of Department of Environmental Science and Management, Faculty of Environment, Thai Nguyen University of Agriculture and Forestry, Vietnam

Ban Thi My - Laboratory technician of Department of Environmental Science and Management, Faculty of Environment, Thai Nguyen University of Agriculture and Forestr, Vietnam

Rudakov Oleg B. - Doctor of Chemical Science, professor, head of department of chemical and chemical technology of materials, Voronezh State Technical University, Voronezh, Russia

Khorokhordina Elena A. - docent of department of chemical and chemical technology of materials, Voronezh State Technical University, Voronezh, Russia 